\title{
Československo-vietnamská kulturní spolupráce ve světle výstav v Náprstkově muzeu
}

\author{
Mgr. Ondřej Crhák \\ Náprstkovo muzeum asijských, afrických \\ a amerických kultur \\ $\triangle$ ondrej.crhak@nm.cz
}

Tento přispěvek vznikl jako součást interniho grantu Národního muzea „Výstavy v Náprstkově muzeu jako součást kulturní diplomacie v letech 1948-1989“.

\author{
Orientalia Antiqua Nova XXI \\ ISBN 978-80-261-1039-2 \\ Západočeská univerzita v PIzni, 2021 \\ https://doi.org/10.24132/ZCU.2021.10392-37-51
}


Vztahy Československa a Vietnamské socialistické republiky jsou $v$ našem prostředí rámovány jistou exkluzivitou. Česká republika nadále rozviji vzájemné vztahy a v zemi je prítomná rozsáhlá vietnamská minorita. Přesto není toto téma častým objektem historiografického bádání. Vzájemné vztahy obou zemí do $\mathrm{r}$. 1989 byly z větší části ovlivněny válečnými konflikty, které se ve Vietnamu odehrály. Zejména válka z let 1964-1975 díky svému trvání a intenzitě zásadně ovlivnila podobu vzájemné spolupráce nejen obou zemí, ale vztahy Vietnamu s celým východním blokem. Spolupráce, respektive pomoc socialistických zemí, se zaměřila primárně na oblast vojenskou, technickou a humanitární. Je samožrejmé, že vedle toho stála rozsáhlá diplomatická podpora Hanoje na mezinárodním poli, kde vedoucí úlohu sehrával Sovětský svaz.

$\mathrm{Na}$ pozadí této podpory běžela spolupráce $v$ oblasti vědecko-technické, vzdělání a kultury. Z našeho zpětného pohledu upozaděná kulturní spolupráce byla důležitou součástí vzájemných vztahů. Obě země měly na této formě kooperace eminentní zájem. Československo využívalo kulturní linii k vlastní sebeprezentaci a $\mathrm{k}$ demonstraci vlastních postojů, které se mnohdy zaměřily na antikoloniální rétoriku. Prezentace se rovněž stala jakousi formou reklamy na československý průmysl a jeho výdobytky, které měly přispět $k$ vytvoření pozitivního obrazu země $\checkmark$ regionu. Vietnamská strana se skrze kulturní záležitosti snažila propagovat své záležitosti ve věci války, kde se snažila představit své cíle a veřejně je obhájit. Nicméně pro vietnamské vedení byla kulturní spolupráce důležitá zejména díky možnosti posouvat vlastní kulturní scénu, která se $v$ moderní podobě začala budovat teprve $v$ druhé polovině 50 . let. Budování pozitivního obrazu obou zemí se dělo prostřednictvím různých médií. Kromě tisku a filmových médií to byly různé kulturní události zaměřené na hudebni vystoupení nebo divadlo. Součástí těchto forem kulturní propagace se rovněž staly muzejní a galerijní výstavy. 


\section{Základní otázky a problémy tématu}

České odborné prostředí je zaměřeno spíše na otázky spojené se současnou vietnamskou minoritou. Vztahy obou zemí byly doposud zpracovány velice okrajově. ${ }^{1}$ Proto je jakékoliv bádání svázáno s primárním bádáním v archivních institucích. Materiály uložené v Národním archivu a Archivu Ministerstva zahraničních věcí jsou často torzovité a neuspořádané, přesto se na jejich základě daři zrekonstruovat diplomatické a politické otázky vzájemných vztahů. Podobný stav je i u dokumentů týkající se přímo muzejních výstav, které jsou uloženy v Archivu Náprstkova muzea a Archivu Národního muzea. Tento příspěvek je předběžnou studií mapující stav této problematiky na počátku bádání. Jedná se de facto o průběžné představení práce v rámci interního grantu Národního muzea, který je zaměřen právě na muzejní výstavy v Náprstkově muzeu asijských, afrických a amerických kultur spojené se zeměmi tzv. třetího světa a které se uskutečnily v obdobní socialismu, tj. v letech 1948-1989. Pro potřeby bádání v oblasti této problematiky bylo vytyčeno několik základních otázek.

První oblastí analýzy je samotný obsah jednotlivých výstav a kontext, ve kterém byly tvořeny. $V$ tomto směru jde o podchycení, jakou ideologickou náplň jednotlivé výstavy měly, zda se v nich objevuje téma antikolonialismu a jak tento diskurz zapadá do celkového obrazu budovaného československým vedením. Podružnou otázkou je zde samotná aktivita Náprstkova muzea, jak do ní podobné výstavy zapadly a zda byly její běžnou součástí. Obecnějši problematiku v příspěvku tvoří otázka role kulturní spolupráce ve vzájemných československo-vietnamských

${ }^{1}$ Nejviditelnějším přispěvkem $k$ této problematice je přehledová kniha Hlavatá 2018 a nevydaná publikace připravovaná pro Ministerstvo zahraničních věcí ČR (Sieber a Zídek 2008). Petr Zídek poskytl autorovi přispěvku část svého textu věnovaného Vietnamu. 
vztazích. Příspěvek se pokusí na tyto základní otázky odpovědět, ale jak již bylo řečeno výše, jedná se o průběžnou publikaci výsledků studia. Proto budou v závěru nadneseny další směry, kudy by se řešení této problematiky mohlo nadále ubírat.

\section{Československo-vietnamské vztahy 1955-1964}

Vztahy mezi Československem a zeměmi francouzské Indočíny nebyly před druhou světovou válkou moc intenzivní. Ani v době Rakousko-Uherska nebyl tento geografický areál prioritou při politickém nebo hospodářském pronikání. Hlavním cílem podobných aktivit byla zejména Čína, která nabízela mnohem více možností. To se odrazilo i na československém exportu v letech 1918-1939. Československé kontakty s Indočínou byly dosti sporadické. Z kraje existence československého státu se do oblasti dostali př́slušníci československých legií při své cestě kolem světa zpět do vlasti z ruského Dálného východu. Dále se do oblasti vypravovali spíše jednotlivci, jako Jan A. Bata, který Indočínu navštívil v roce 1937 během svých cest. Francouzská politika v Indočíně byla zaměřená na protežování vlastních firem a na monopolním exportu určitých druhů zboži. Pro země jako Československo by bylo nepř́liš rentabilní takovéto překážky překonávat, a tak i samotný Bata po své cestě zhodnotil Indočínu jako nepřiliš vhodnou zemi pro investování. ${ }^{2}$ Československá zdrženlivost trvala de facto až do poloviny 50 . let.

Situace ve Francouzské Indočíně se rapidně změnila po roce 1945. V zemi zesílilo národněosvobozenecké hnutí a došlo k prvnímu válečnému konfliktu mezi nově vzniklou Vietnamskou demokratickou republikou a Francií, který byl ukončen roku 1954. Do této války se aktivně zapojila pouze Čínská lidová republika, která do Vietnamu dodávala vojenský materiál a zajištovala

${ }^{2}$ Hlavatá 2008, 404. 
výcvik vojáků. Země východního bloku v čele se Sovětským svazem zůstaly po celou dobu konfliktu stranou. Moskva se pak jen zapojila do mírových jednání v duchu snižování světového napětí. Československou stopu v této válce tvoří přislušníci francouzské cizinecké legie, kteři byli původně občany Československa. ${ }^{3}$ Po celou dobu války byla naprosto zdrženlivá, byt Vietnamskou demokratickou republiku uznala hned $v$ únoru 1950. Vzájemné vztahy byly limitovány na běžné záležitosti, ze kterých vyčnívala hlavně agenda ohledně zajatých Čechoslováků bojujících na straně Francie a jejich následné repatriace. Jiné vietnamské pokusy o získání diplomatické nebo politické podpory $v$ Praze byly neúspěšné. ${ }^{4}$ Roli $v$ tom sehrál fakt, že $\checkmark$ rámci československého státního a stranického vedení byla otázka Indočíny poměrně neznámá a nikdo se $v$ ní díky geografické a jazykové bariéře nevyznal. ${ }^{5}$ Zásadním faktorem pro zdrženlivost nejen Československa, ale i jiných socialistických zemí byla snaha nepoškodit poměrně dobré vztahy s Franciii. ${ }^{6}$

Po skončení války se vztahy mezi Vietnamem a východním blokem začínaji pomalu měnit. Kromě mírové situace $\mathrm{k}$ tomu přispěla i změna v oblasti zahraniční politiky Sovětského svazu. Do roku 1953 byla sovětskou prioritou zejména Evropa. Výjimku tvořila válka v Koreji, ale ostatní asijské otázky zůstávaly upozaděny. Kromě strategické roviny $v$ tom hrály roli i Stalinovy osobní postoje, které byly zatiženy rasistickými předsudky vůči Asiatům. ${ }^{7}$ Destalinizace spouštěná Chruščovem na XX. sjezdu Komunistické strany Sovětského svazu zasáhla i oblast zahraniční politiky a strategického vnímání mimoevropských oblastí. Proto pak i další státy ze sovětského bloku přistoupily na nový

\footnotetext{
${ }^{3}$ Hlavatá 2008, 405-407.

${ }^{4}$ Sieber a Zídek 2008.

${ }^{5}$ Kudrna 2010, 316.

${ }^{6}$ Kudrna 2012, 72.

${ }^{7}$ Chruščov 2000, 156-157.
} 
kurz. ${ }^{8}$ Novou fázi vzájemných vztahů odstartovalo otevření československé ambasády v Hanoji v lednu 1955.

Vietnamská demokratická republika se nacházela ve špatné hospodářské a sociální situaci, a tak hned požádala socialistické státy o pomoc. Československo hned v záři téhož roku na základě dohody o hospodářské spolupráci poskytlo finanční dar $\checkmark$ hodnotě 45 milionů Kčs a dodávky pro strojírenství a jiného zboží. Kromě darů obsahovala dohoda i dodávky československého zboží, které měly být pokryty finanční půjčkou. Smlouva taktéž zajistila studium prvních třiceti vietnamských studentů na československých školách, jejichž studijní výlohy byly pokryty československou vládou. ${ }^{9}$ Československo také poskytlo dočasný azyl přibližně stovce vietnamských sirotků, kteři byli umístěni v dětském domově v Chrastavě. ${ }^{10}$ Další půjčky a pomoc byly pak poskytnuty na základě dohod v roce 1958 a 1959 . Spolu s finanční a materiální pomocí vysílalo Československo do Vietnamu své experty, kteří měli na místě školit své vietnamské kolegy a zároveň pomáhat při budování průmyslových podniků. $\checkmark$ této oblasti měla Praha enormní zájem o participaci na těžbě nerostných surovin, a to zejména antracitu, proto mnoho expertů vyslaných na místo operovalo bud' $v$ oblasti geologie nebo hornictvi. ${ }^{11}$ Humanitární pomoc se projevila v otevření československé nemocnice v Haiphongu, která byla v provozu od roku 1957. Nemocnice byla vysoce ceněná a byla považována za moderní zařizení, díky čemuž vietnamská strana opakovaně žádala o prodloužení tohoto projektu, který měl skončit v roce $1958 .{ }^{12}$

\footnotetext{
${ }^{8}$ RGANI, fond 1, op. 5, rol. 1003.

${ }^{9}$ AMZV, TO Vietnam 1955-59, k. 2.

${ }^{10}$ Hlavatá 2008, 411.

${ }^{11}$ AMZV, TO Vietnam 1955-59, k. 2 a 3.

${ }^{12}$ AMZV, TO-T Vietnam 1955-59, k. 4.
} 
Ruku v ruce s rozkvětem hospodářských vztahů docházelo také ke zlepšení kontaktů na politické úrovni. Kromě výměny stranických a nižších vládních delegací lze za vrchol počitat státnické návštěvy. Ho Či Min navštivil Československo již v červenci roku 1957 v rámci svého turné po zemích východního bloku. ${ }^{13}$ Stejně tak generální tajemník ÚV KSČ a prezident republiky Antonín Novotný navštívil Vietnam, ovšem až v lednu $1963 .{ }^{14} \mathrm{Na}$ přelomu 50. a 60. let ovšem došlo k mírnému ochlazení nebo spiše k menším komplikacím ve vzájemných vztazích. $Z$ geopolitického hlediska tomu bylo z důvodu počínající čínsko-sovětské roztržky, ve které se Hanoj dlouhou dobu stavěla na stranu Pekingu. Tento postoj vyvolával přinejmenším opadnutí zájmu a důvěry mezi Vietnamem a východním blokem. ${ }^{15}$ Situaci ještě komplikovala hospodářská situace ve Vietnamu, díky které byly jakékoliv ekonomické aktivity pro Československo nevýhodné. Přes tyto komplikace docházelo nadále $\mathrm{k}$ rozvoji finanční a hospodářské pomoci. ${ }^{16}$

\section{Kooperace v oblasti kultury}

Spolupráce v oblasti kultury byla nejen doplňkovou činností politických a ekonomických aktivit obou zemí, ale jejich přimou neméně důležitou součástí. $V$ obecné rovině můžeme kulturu hodnotit jako prostředek, kterým se oba režimy snažily komunikovat se svou vlastní společností. Tento nástroj komunikace byl součástí procesu otevírání nových témat a v podstatě utvárení diskurzu pod kontrolou státu. $V$ rovině mezinárodní je pak kultura prostředkem sebeprezentace a možností, jak vlastnímu veřejnému mínění představit své spojence.

\footnotetext{
${ }^{13}$ NA ČR, ÚV KSČ A. Novotný II., č. 560, k. 228.

${ }^{14}$ NA ČR, ÚV KSČ A. Novotný II., č. 559, k. 229.

${ }^{15}$ Friedman 2015, 102.

${ }^{16}$ Sieber a Zídek 2008. AMZV, TO-O Vietnam 1960-64, k. 2.
} 
Stejně jako ostatni oblasti byla spolupráce $v$ oblasti kultury vymezena patřičnými dohodami. $V$ březnu roku 1957 byla uzavřena smlouva o kulturní spolupráci s platností na pět let. Dohoda presně definovala, jakých aktivit se bude kulturní výměna týkat. Kromě vzájemných návštěv uměleckých souborů se zabývala také pracovní výměnou zaměstnanců přislušných institucí, která měla vést $k$ transferu zkušenosti. ${ }^{17}$ Vedle oficiální roviny kooperace mezi velkými státními institucemi se do výměny zapojily i nevládní organizace. Např́klad Svaz československých spisovatelů vedl poměrně četnou komunikaci se svými vietnamskými protějšky. Tyto kontakty pak umožnily překládání československé a vietnamské literatury a její následnou distribuci v obou zemích. Plány na spolupráci byly tvořeny vždy na jeden rok dopředu a jejich obsah se často odvijel od požadavků vietnamské strany nebo československého velvyslanectví v Hanoji. ${ }^{18}$

Specifickým požadavkem vietnamské strany byla pomoc a spolupráce ve věci filmového průmyslu. Hanoj projevovala enormní zájem o československý film a vysílání jeho pracovníků do Vietnamu. Např́klad v letech 1956-1957 odjeli do Vietnamu pracovat filmaři Jaroslav Novotný a Ján Cifka. Z jejich cesty vznikl dokumentární film a řada fotografií, které pak byly prezentovány na výstavě v hale FOMA roku 1959. ${ }^{19}$ Vietnamský zájem o film se mimo jiné projevoval v účasti vietnamských filmů na různých festivalech. Pravidelnou se stala účast vietnamské delegace na Mezinárodním filmovém festivalu v Karlových Varech, kde byly prezentovány i vlastní vietnamské snímky. ${ }^{20}$ Československá strana si vietnamský zájem o film plně uvědomovala, a tak běžnou záležitostí bylo prezentování vlastního filmového průmyslu

\footnotetext{
${ }^{17}$ Do Vietnamu zavítal Armádní umělecký soubor Víta Nejedlého nebo soubor divadla Laterna Magika. AMZV, TO Vietnam 1955-59, k. 2.

${ }^{18}$ AMZV, TO Vietnam 1960-64, k. 2.

${ }^{19} \mathrm{NM}-\mathrm{NpM}$, Dokumentace výstav, č. 35/72, k. 11.

${ }^{20}$ AMZV, TO Vietnam 1960-64, k. 3.
} 
př́mo ve Vietnamu. Ambasáda v Hanoji často organizovala menší filmové festivaly, které byly uskutečněny $k$ významnému výročí. Například v roce 1960 byl uspořádán festival k 15. výročí osvobození Československa. Zajímavé je, že promítané filmy na této události byly zakoupeny vietnamskou stranou. ${ }^{21}$

Stejně jako v připadě ekonomických vztahů došlo k mírnému ochlazení na poli kultury. Částečnou nekoncepčnost spolupráce po roce 1960 způsobilo nedodržování dohodnutých plánů, respektive konání událostí a aktivit mimo tyto dohody, do kterých pak byly retrospektivně doplněny. Komplikace se objevovaly hlavně ve formě laxnějšího přistupu a častých zpožděni. ${ }^{22}$ Otázkou zůstává, zda to bylo způsobeno politickou situací ohledně čínsko-sovětské roztržky nebo vnitřní situací ve Vietnamu, kde se pomalu, ale jistě schylovalo $k$ dalšímu konfliktu.

Výměna pracovníků $v$ kultuře se týkala i Národního muzea a jeho složek, tedy i Náprstkova muzea. Národní muzeum bylo zapojeno do výměny pracovníků ze spřátelených zemí, kterým nabízelo možnost studia vlastních sbírek. Nutno podotknout, že pro státy jako Vietnam je samotný koncept "národního muzea“ zajímavý a nosný pro vyprávění vlastního národního přiběhu. Nicméně na rozdil od filmu nebyla $v$ materiálech vietnamská aktivita zachycena. Tento rozdíl byl zřejmě způsoben poměrně krátkým mírovým obdobím a následnou válečnou eskalací, která prípadné snahy odsouvala na druhou kolej. ${ }^{23}$ Kromě takovéto ideové výměny umožnily vzájemné dohody rozvoj odborného bádání. Náprstkovo muzeum na této bázi vyslalo do Vietnamu svoji pracovnici Evu Rychterovou-Kreisovou za účelem terénního výzkumu v provincii Thai Bing v severní části země. Výzkum byl zaměřený na podobu a proměny vietnamské vesnice. ${ }^{24}$

${ }^{21}$ AMZV, TO Vietnam 1960-64, k. 2.

${ }^{22}$ Tamtéž.

${ }^{23}$ ANM, Registratura NpM, k. 36.

${ }^{24}$ Tamtéž, k. 44. 


\section{Muzejní výstavy}

Výstavy obecně byly vždy součástí vzájemných kulturních plánů. Jednou z kategorií, které se v tomto plánování objevují, jsou putovní výstavy, které cestovaly napřič mezi spřátelenými zeměmi. Jednou takovou výstavou byla československá výstava „Péče o matku a dítě“, která se do Hanoje dostala v roce 1960 z Mongolské lidové republiky. Tato výstava byla víceméně reklamou na Ústav pro péči o matku a dítě, který byl založen v Praze na počátku 50. let. Zde se jedná o exemplární př́pad propagace československé vědy a Československa jako pokrokové země obecně. ${ }^{25}$ Náplň putovních výstav byla různorodá, mnohdy se jednalo o prímou propagaci československého průmyslu skrze fotografie nebo byla náplň čistě politická. Tuto rovinu Ize vidět ve výstavě „15 let osvobození ČSR“, kde docházelo k demonstraci dlouhodobosti boje proti fašismu a jednoty bloku. Druhá světová válka byla dobrým pojítkem, kde se mohl spojit zmíněný boj proti fašismu, antiimperialismus $s$ antikoloniální agendou, což mohlo v určitých regionech dosti rezonovat. ${ }^{26}$

Podobně postupovala vietnamská strana, která ve svých výstavách otevírala témata spojená $s$ vlastní kulturou a válkou. ${ }^{27}$ Partnerem pro takové aktivity se díky svému zaměření na mimoevropské oblasti stalo Náprstkovo muzeum. Vyjma těchto externích výstav byla řada vytvořena čistě autorsky $v$ této instituci. $V$ dotčených archivech existují záznamy celkem o osmi výstavách dotýkajících se Vietnamu z let 1954-1981. Zajímavé je, že jejich četnost se situovala do dvou dekád. Nejvíce uskutečněných výstav bylo právě v 50. a 70. letech. Během 60 . let, kdy se vietnamská válka rozhořela naplno, však neexistuje

\footnotetext{
${ }^{25}$ AMZV, TO Vietnam 1955-59, k. 2.

${ }^{26}$ AMZV, TO Vietnam 1960-64, k. 2

${ }^{27}$ Jednalo se zejména o výstavu „15 let Vietnamské demokratické republiky“. NM-NpM, Dokumentace výstav, č. 20/20, k. 14.
} 
žádná výstava s tímto tématem. Ty přicházejí až ve zmíněných 70. letech. Př́činy takového stavu mohou být dvojí. Jednou rovinou je toliko zmíněná politika a malé turbulence ve vzájemných vztazích. Druhou je čistě praktická rovina týkající se odborné vybavenosti pracovníků muzea. Vietnamistika byla a je navzdory svému významu poměrně malým oborem a nemohla tak rychle dodávat kvalitní absolventy, kteří by prováděli případnou činnost $v$ této oblasti. Stav dokládá již zmíněný terénní výzkum Evy Rychterové-Kreisové, která byla primárně sinoložkou. Potřeby týkající se zejména jazykových záležitostí řešilo muzeum najímáním vietnamských studentů. ${ }^{28}$ Navzdory této situaci se však muzeum takové činnosti nevyhýbalo. Otázkou zůstává, z jakého důvodu tedy existuje mezera $v 60$. letech a nárůst v následující dekádě. Je jasné, že určitou roli v tomto sehrály osobni preference pracovníků. Na druhé straně impakt politických událostí a následné „politické objednávky“ nelze vyloučit. Archivní dokumenty zatím na toto neposkytly odpověd'.

Dokumenty týkající se uskutečněných výstav bohužel neukazují na jejich politické pozadí, avšak dovoluji aspoň zčásti rekonstruovat jejich poselství nebo obsah. $V$ obecné rovině Ize říci, že $v$ rámci výstavních aktivit bylo silně akcentováno téma boje proti kolonialismu. Tento diskurz zasáhl rovněž výstavy, které byly tvořeny externími autory a Náprstkovo muzeum jim bylo partnerem. Jednou z takových akcí byla výstava obrazů maliře Jiřího Schmidta. Doprovodné texty $k$ výstavě odráži dobový diskurz o neštastně rozděleném vietnamském národě a o zemi, která je na základě ženevských dohod z roku 1954 rozdělená na sever a jih "nespravedlivou 17. rovnoběžkou“. Samotný program vernisáže silně přijímá antikoloniální jazyk: "Běda těm, kteří se v Asii cítí o hlavu větší Asijců jenom proto, že fysicky vyrostli!" Výstava se na druhou stranu také dotkla

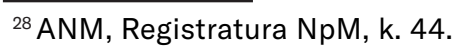


nepříznivé situace $v$ poválečném Vietnamu, kdy se v zemi rozmohl hladomor. ${ }^{29}$

V podobném duchu se připravovala výstava týkající se Vietnamu přímo v Náprstkově muzeu v polovině 50. let. Expozice měla vyprávět přiběh Vietnamu od počátků francouzské kolonizace Indočíny až po vyvrcholení národního osvobození a založení Vietnamské demokratické republiky. Dá se tedy konstatovat, že poselství výstavy bylo silně antikoloniální a mělo zřejmě představit novou politickou agendou spojenou s trendem dekolonizace. Texty spojené s expozicí často zmiňovaly pojmy jako francouzská koloniální válka nebo plundrování veškerých zdrojů v Indočíně ze strany Francie. Součástí vyprávění byla rovněž historie Vietnamské komunistické strany, odborové hnutí a otázka ženské emancipace. Vietnamská kultura byla zastoupena pracemi tehdejších vietnamských umělců. ${ }^{30}$ Muzeum působilo také ve veřejném prostoru, tj. konalo výstavní činnost mimo vlastní budovu. Příkladem jsou drobné výstavy, uskutečněné ve vestibulu metra Muzeum. Jedna z nich se přímo zabývala Vietnamem, nesla název „Vietnamský lid vždy zvítězil nad agresory“ a byla realizována $v$ roce 1979 . Archivní zdroje zatím nedokázaly odhalit její obsah. ${ }^{31}$

\section{Závěr}

Závěrem Ize konstatovat, že doposud probádané výstavy víceméně souzněly s politickým diskurzem zaměřeným na dekolonizaci. U většiny z nich je ve větší či menší míře využiváno antikoloniálního jazyka. Často byla též využivána témata, která jsou bud' přímo navázána na boj za národní osvobození nebo vychází

\footnotetext{
${ }^{29}$ NM-NpM, Dokumentace výstav, č. 35/63, k. 11.

${ }^{30}$ NM-NpM, Dokumentace výstav, č. 27/38, k. 8.

${ }^{31}$ ANM, Registratura NpM, k. 36.
} 
z modernizační agendy komunistických stran. V zásadě se jednalo o demonstraci tohoto postoje, která byla primárně určená domácí společnosti za účelem ovlivnění veřejného mínění. Není jasné, do jaké míry se jednalo o práci na zadání z vysokých míst, aktivitu muzea nebo osobní postoje jejich autorů. Tato otázka zůstává stále nezodpovězena a bude v ní třeba dalšího bádání. Výstavy v obecném slova smyslu byly nedílnou součástí kulturní politiky v rámci mezinárodních vztahů nejen $v$ období studené války. Expozice jako takové totiž tvoři poměrně jednoduché médium, skrze které Ize sdělit komplexní informaci v poměrně líbivém vizuálním podání.

Spolupráce na kulturním poli dávala Československu, ale i Vietnamu, možnost prezentovat vlastní stát a jeho výdobytky. Československo tak propagovalo nejen vlastní cestu socialismu, ale i svůj průmysl a vědu, čímž se snažilo vytvářet obraz spolehlivého partnera. Ten se následně mohl využít v dalších zemích. Vietnamská strana krom propagace vlastních politických a strategických cílů využívala kooperaci jako prostředek při budování vlastní moderní kultury. Příkladem tohoto postupu byl enormní vietnamský zájem o československý filmový průmysl. Kooperace se zeměmi východního bloku byla prostředkem, jak získávat zkušenosti a vychovávat si tak vlastní kvalitní odborníky v poměrné krátkém čase.

Podíváme-li se na tuto problematiku optikou Náprstkova muzea, jsou výše zmíněné výstavy naprosto běžnou součástí jeho činnosti v letech 1948-1989. Díky archivním dokumentům Ize vytvořit jednoduchý chronologický přehled expozic a četnost těch, které nějak souvisí se zeměmi tzv. třetího světa a dekolonizací je velice častá. Jelikož je tento příspěvek ve své podstatě průběžnou zprávou ze studia této problematiky, tak krom poskytnutí odpovědí na již nadnesené otázky otevírá otázky nové. Další studium problematiky by se proto mělo zaměřit na to, jak bylo 
řízeno a kontrolováno samotné vytváření výstav. Vyřešení tohoto problému nám umožní odpovědět na otázku, jak moc byla výstavní činnost řizena centrálně a jakou míru autonomie Národní muzeum $v$ této aktivitě mělo.

\section{Bibliografie a zdroje}

Archiv Ministerstva zahraničních věcí

AMZV, TO Vietnam 1955-59, k. 2.

AMZV, TO Vietnam 1955-59, k. 3.

AMZV, TO-T Vietnam 1955-59, k. 4.

AMZV, TO-O Vietnam 1960-64, k. 2.

AMZV, TO Vietnam 1960-64, k. 3.

Národní archiv ČR

NA ČR, ÚV KSČ A. Novotný II., č. 560, k. 228

NA ČR, ÚV KSČ A. Novotný II., č. 559, k. 229

\section{Archiv Náprstkova muzea}

NM-NpM, Dokumentace výstav, č. 27/38, k. 8 NM-NpM, Dokumentace výstav, č. 35/72, k. 11 NM-NpM, Dokumentace výstav, č. 35/63, k. 11 NM-NpM, Dokumentace výstav, č. 20/20, k. 14

\section{Archiv Národního muzea}

ANM, Registratura NpM, k. 36

ANM, Registratura NpM, k. 44 
Ruský národní archiv pro soudobé dějiny

RGANI, fond 1, op. 5, rol. 1003

\section{Literatura}

Friedman, Jeremy. 2015. Shadow Cold War: The Sino-Soviet Competition for the Third World. Chapel Hill: University of North Carolina Press.

Hlavatá, Lucie (ed.). 2018. Dějiny Vietnamu. Praha: Nakladatelství Lidové noviny.

Chruščov, Nikita Sergejevič. 1999. Vzpomínky Nikity Sergejeviče Chruščova: Magnetofonové nahrávky z obdobi glasnosti. Praha: Jota.

Kudrna, Ladislav. 2010. Bojovali a umírali v Indočíně. Praha: Ústav pro studium totalitních režimů, Naše vojsko.

Kudrna, Ladislav. 2012. První vietnamská válka na pozadí osudu Ladislava Charváta. Praha: Academia.

Sieber, Karel a Petr Zídek. 2008. Československo a země jižní a jihovýchodní Asie v letech 1945-1989. Praha: MZV. 